\title{
Existing Social Justice Choice for Underprivileged Society Members
}

\author{
Pheni Chalid \\ Social Economist, Faculty of Economics and Business, \\ Syarif Hidayatullah State Islamic University of Jakarta \\ pchalid@uinjkt.ac.id
}

\author{
Astrid Nadya Rizqita \\ Activist, Youth on Organization of Islamic Cooperation \\ Indonesia
}

\begin{abstract}
This research is intended to look for strategic approach and access on justice for under-privilege groups in society. The research will highlight two types of communal justice, namely positive justice, based on formal structure that is used to solve legal cases and social justice, a steadier form of justice that uses social wisdom to achieve justice. Positive justice is often linked with complicated bureaucratic processes, lubrication payment, procedure oriented, and only approving of those who have access to more economic capital. This research stipulates that there is a gap between those who are aware about their rights and legal access, have access to capital and those who lack the apt knowledge, economic resources, and legal access. It is assumed that the gap to access legal services draws upon the issue of economic inequality. It founds that capitalization of legal access outdoes the traditional rights embedded in society, namely territorial law, land based on societal culture. Alleviation of justice gap can be done by making use of existing institutions and local wisdom that are based on social and cultural capital. Social network approach to conflict is deemed less costly, hence accessible for the underprivileged society members who have been deprived of justice.
\end{abstract}

Keywords - Law Capitalization; Social Justice; Inequality; Social Networks; Local Wisdom

\section{INTRODUCTION}

Law is a formal way used to create a social order as a social control system in tribal societies as well rural societies, and can be in the form of government or non-government (Benda-Beckmann, 2002). Recently, the law is more understood as a positive rule which believe that justice can be maintained by its legal apparatuses. Apart from natural law that is law by God, natural, and other absolute sources, in this research we highlight two types of justice systems. Positive justice is justice what the law announces as just. It is based on a formal structure and procedure and is used to solve legal cases with the use of the authorized legal apparatuses. It is often signified with the police, judges, prosecutors, attorneys, and others. Adherence as well as abidance to the existing law system that has been established by the government authorities is an accepted measure of government legitimacy. Another justice system is known as social justice that is derived from cultural values and practiced as local wisdom. Country people are accustomed to live and to be familiar with its eternal values and long lasting impact of any result conflict resolution in society.
With the assurance of a just system and professionalism, positive justice is a popular resort among the educated and middle to upper class segments of society. However, there is a price to pay in terms of dealing with the procedures and the practices of positive justice system. Being a part of public service, positive justice is often linked with complicated bureaucratic processes, long queues and lack of organization. The unjust tendency of state justice systems renders as a disincentive for society members coming from simpler societies to seek justice.

This research is considered as a sociological-empirical legal approach. Empirical legal research is started by the comprehension of normative aspect in relation to legal application practicality. The use of socio-legal approach in this study is intended to attain an understanding of existing formal justice, namely the positive justice practices based on institutional law in accordance with socio-cultural of society, with a focus on underprivileged members of society.

\section{DISCUSSION}

\section{A. Social Justice}

There is a distinct dread when people have to deal with the complicated existing bureaucracy practices, and it is much prevalent within developing economies, in which lubricant money is often used for those who wish to slide through the process to get legal services. It can be hypothesized that the ones who are aware of their rights to have legal access, knowledgeable and economically empowered have comparatively more advantage in terms of getting legal services. As such, the scope of positive justice has not sufficed the needs and grievances of the underprivileged members of society, the ones who lack the adequate knowledge, economic resources, and in turn, lack of access to justice.

In addition, there may be some members of the society who have enough knowledge and awareness of legal services in times of grievances. However, the predisposition that they have on positive justice discourages them to seek further consultation with the formal legal services. On the other side, scandals that may arise result in the lack of trust formed along the years of revealed corruption among the legal officials 
themselves does adverse effects on the trust of society, especially the underprivileged society members, towards the existing official legal system. The heavy emphasis put upon the procedural aspects of positive justice becomes a fertile ground for the use of economic capital as a lubricant to get by the legal process. Such as the recent case of Setya Novanto, Indonesian national legislative speaker, against the administrative court, in which procedural aspects outweighs the substantive aspects. It creates a pseudo-power within the legal apparatus themselves. In addition, it is commonly known by public that some corruptors are sentenced only in short period to jail and have lux facilities during their stay in the jail.

Acknowledging and experiencing moral hazards in attaining justice within formal judicial procedures has driven a common understanding among citizens that formal justice is not only expensive and full of procedures but also leak. As a consequence, people diminish their trust to the process, institution, judicial apparatuses and the product of court house. Justice and trust is two sides of a coin. If justice on the hand of apparatuses is only a lip-service, the trust will wipe away. It is really difficult to get it back (Chalid, 2016). On the other hand, another justice system that the society may opt for is social justice, much more common in country side and traditionally-knit communities. Social justice, which is commonly implemented within rural societies, is considered as one of the solutions to obtain a sense of justice and is also common due to the low cost associated with it. In normal situations where positive justice is used, when conflicts arise, the matter if taken to court, along with a fee that needs to be paid, something that the underprivileged cannot bear to afford (Bedner, 2010). Should the under-privileged still opt for court to resolve a strife, they seldom attain the justice they deserve, merely due to lack of economic resources as a bargaining position against their rival.

Therefore, the capitalization of legal process serves as one of the constraints wherein the positive justice cannot cater to the underprivileged members of society. Ensuing this phenomenon would then result in a much greater divide between the knowledgeable and the less-informed, the rich and the poor. In this case, justice not only refers to legal and social aspects but also pertains to economic well-being. Capitalization of legal access outdoes the traditional rights instilled within the society, namely territorial law, land ownership based on societal culture and justice (Franco, 2010). Similarly, after the land has been attained, the externality costs of the traditional society has to be born including the construction waste and environmental pollution caused by construction of factories, along with their everreceding land ownership due to forceful plotting by the private sectors. It seems that the settlement mechanism by the formal judiciary system somehow enforces the will of the people with higher economic status or capacity, such as the big companies because they are able present proper legal papers in court. As a consequence, the existing judiciary system causes more divide and diminishes any form of trust (Susan, 2015).

\section{B. Resolving Conflict through Social Network}

Apart from the formal justice system, namely the positive justice or the top-down approach to justice, societies that are adherent to their traditions and customs are also ruled by their own customary laws, dating back to their origins and local wisdom. By abiding to their customary law that is unanimously agreed upon, it ensures that societies that are remote and far from the district office or governmental agencies including district court still can have access to their required form of justice, although informal in nature.

The local wisdom providing a sense of justice is a form of informal justice, as the practices and the mechanism is distinct from official state policy. As a result, state apparatuses and other formal legal providers are not a part of this mechanism (Wojkowska, 2006). As such, what is called as informal justice are run by locally claimed authorities, such as tribal leaders, religious figures, the local leaders, or other highly respected members of the community. Social justice, in this case is informal, due to the methods and mechanisms that do not incorporate official elements from the state, as well as the figures involved in helping to resolve the issue at hand. Moreover, the costs incurred may be less, or even does not incur costs at all.

Social justice serves as a feasible solution for the reasons of low cost, already established within existing cultural environment, and steadier in nature. As stipulated by local wisdom, namely in Java and Madura culture, closely-knit nature of the rural communities establishes a form of paramount trust and sense of authority given to mainly three figures in society, namely the religious leaders, tribe leaders, and chieftains (Nugroho, 2015). The three aforementioned figures are adequate to help solve conflicts and disputes among tribesmen and the most reachable and feasible option, noting that it takes six to seven lines of state authorities for each tribe member to reach the country leader. Therefore, social networks aim to make use of the already-existing institutions that are non-bureaucratic and at the same time preserve and uphold the local wisdom within the society.

The mechanism of social network as a form of social justice involves the youth activist in a region who can operate basic forms of communication technology. They serve to notify the authorities, such as the police, prosecutors, and the local government representatives. These justice agents at the micro level help the community, and in turn the society to become aware of their rights. Moreover, an increased sense of awareness will prevail in terms of illegal practices which may have otherwise been considered lawful prior to the existence of social network as a form of social justice.

The urge to have mobile justice agents in a society which have been lacking access to legal services, has been echoed throughout other nations. One such example is the need for access to information, in which the government provides transparency to society members and increases access for society to share their aspirations, critiques, or grievances (Puddephat, 2009). Essentially, the justice agents within the social network represent four important aspects, namely, improving access to information, increasing awareness of society on the importance of seeking justice, improving 
awareness of society on wrong practices of justice which may have persisted in the society for years and creating a bridge between the grievances with the adequate justice they deserve.

Furthermore, while social justice is deemed a feasible option, it must also be taken into consideration that the main discourse present is on increasing access for the underprivileged members of society (Röder, 2013). Having addressed the issue of the cost, time, knowledge, as well as economic constraints, oftentimes the problem underlying the need for social justice as an alternative to formal, positive justice rests upon the nature of the conflict at hand. In essence, petty conflict that does not necessarily require the involvement of state legal apparatuses would be efficiently resolved within the confines of their own area, in accordance to their customary laws. It would be efficient not only for those filing for grievance, but also for the government at large, as the state apparatuses would have more space to resolve the queueing trials and matters which may be more ardent to be resolved.

\section{Legal Pluralism}

Pancasila, the country's ideology, combines the active contribution of the state in realizing the prosperity of its citizens as well as keeping into consideration individual interests at the same time. Hence there should be a balance between the role of state and the individual role in terms of economic as well as justice aspects (Nugroho, 2015). As such, legal pluralism involves aspects that merge the role of smaller communities as well as the formal justice apparatus to cater the needs of the underprivileged. This is because it costs less for the country to support, does not burden the underprivileged and results in a higher satisfaction among the beneficiaries as their rights have been fulfilled.

Legal pluralism has been in practice within nations that are diverse in nature, and those that have gaps in terms of customs and access. Consequently, it signifies that while state laws are enforced at a national level, by the state, and the legal apparatuses, customary laws exist in the remote and traditional members of society (Gebeye, 2017). Official legal apparatuses and other state institutions attain their legitimate status from the existing and approved national legislation. However, in the much smaller scope of traditional society, customary law, which in the eyes of the state is informal justice, is treated and met with more approval as well as acceptance by the traditional communities.

In order for social justice to be effective, it should be based on the assumption that the traditional society is not as heterogeneous in nature. A more homogenous society indicates that all layers of the members of society have more common values than differences, as well as adhering and upholding similar values (Röder, 2013). In addition to that, ensuring the fair and equal access to justice for these members of society also requires a form of recognition by the state apparatuses that these traditional members of society have a unanimously accepted and embodied for of social justice present in the society.

As a result, what is being signified as legal pluralism is the incorporation of both the formal justice system, or referred to as the positive justice system and the informal justice system, or social justice by local wisdom. In order to do so, it requires an acknowledgement as well as recognition by the state on the customary laws existing within the traditional societies. On the other hand, the traditional society may also be aided by justice agents, comprising of youth who are well informed about technology and can help as a bridge. They serve not only to bridge the members of society in terms of grievances to legal service providers, but also serve as a bridge between the members of society who have been unaware and uninformed about justice to be aware of justice and the need to take action when it is required.

\section{Social Wisdom in Practice}

In terms of resolving disputes within the society members, the cultural community possesses their own customary law (Nwocha, 2016). In North Maluku, should a territorial dispute arise, the disputing sides are mediated by having a little contest in which a representative of each side holds his or her breath underwater. The local wisdom of such conflict resolve is that the liar amongst both parties would not be able to stay in the water for long, due to more anxiety on their flowing blood and quicker heart rate pace. On the other hand, the one who has been truthful would emerge from the water last because it is believed that when someone has nothing to hide they would be able to stay calmer underwater. When the winner of the contest has been determined by the mediator, possibly the local leader or tribe leader, the losing side will accept it without any resentment, so peace will be sustained. Such social justice is to be institutionalized and be a less costly option for the government to increase access for justice among underprivileged society members.

Another form of social wisdom hails from Ternate, in which for years a minority group have been working and helping as servants for the leader of a kingdom. The servants do not come from the area they work in, whereas a time comes when their homeland have vanished and they have no option left other than staying within the territory of the kingdom. The servants' family members have grown year to year and need more space to live. The king did not know of the case for a long time. After appealing to the king and describing the real matter that the servants face, the king decided to give his servants residential status so that they become legitimate in the kingdom. In this case, the local wisdom serves as social justice, in which the ruler of the area, or a tribal leader is highly regarded in their society, and being their king, ultimately has the control of the law, and the leader himself uses his authority to give justice to his servants in the form of acknowledging their rights as hard-working workers and granting them living space..

\section{E. Local Wisdom and Social Justice Choice in terms of Economic Perspective}

Traditional convictions are ingrained and embodied. It would be adverse in the perspective of formal legal system which has been running for years in a rural, traditional society may be an arduous task to shift for the better. While domestic violence is not tolerated in Ternate, some community members are resistant to the settling of such cases through the formal legal system (UNDP, 2014). Domestic violence has 
traditionally been viewed a private matter to be dealt with by family members according to adat (social customs).

Diminishing trust of society members to formal justice system and moving to social and cultural justice practices were well recorded from the evaluation result of LEAD a UNDP-BAPPENAS projects in different provinces such as Central Sulawesi, East Sulawesi, North Maluku and Bangka Island.

\section{Access Choice}

to Legal Services of LEAD Project Beneficiaries

\begin{tabular}{|c|c|c|}
\hline No. & Legal Services Choice & Beneficiaries \\
\hline 1. & Community Services & $26 \%$ \\
\hline 2. & LBH or paralegal & $43.8 \%$ \\
\hline 3. & Other legal assistances & $35.4 \%$ \\
\hline 4. & Village Head & $45.8 \%$ \\
\hline 5. & Government Staff Member & $22.6 \%$ \\
\hline 6. & Religious Leaders & $42.7 \%$ \\
\hline 7. & $\begin{array}{l}\text { CSOS, citizen advisor, complaints or } \\
\text { information post }\end{array}$ & $49.7 \%$ \\
\hline
\end{tabular}

Source: LEAD Impact Assessment 2011

Justice providers include those from the state and nonstate ones. The state justice providers namely local and national government, law enforcement bodies, service provision agencies and, the non-state ones including, CSO grantees, customary and village level dispute resolution committees to better address the grievances of the poor and vulnerable. Several initiatives and programs have been undertaken, namely the UNDP-LEAD Project, aiming to increase legal empowerment of the disadvantaged group (UNDP-BAPPENAS, 2014).

The scope of disadvantaged groups in that case is the women, blue collar labor, minority groups, and communities in isolated territory. It has been found based on the LEAD Project report that the target beneficiaries has improved their willingness as well as access to legal services, namely the citizen advisors, village heads, and religious leaders. These three providers are the three key figures that are most trusted and revered by the traditional society, especially in the decentralized Indonesia (Pal, 2010). The research suggests that in rural areas, the society members' access to legal services do not necessarily have to come from state justice providers. It shows that access to non-state justice providers, in this case from local wisdom and social network, is the most feasible choice for those underprivileged in society.

In addition, the formal legal services may be timely and costly. To file for grievances, the underprivileged must travel all the way to district court. They must be present in court and also require a professional lawyer. Until the issue is resolved, they are to set aside their personal schedule to be presented in the court house. The more remote their home from court house is, the more expensive the cost will be. It takes time to follow the existing procedure in formal justice and to compete with other trials as other members of societies have also the right to file grievances as well. Should a rejection occur, submitting an appeal incurs another cost on them. It takes time to process the appeal and if they persist to continue appealing after rejection, the case would end up in Supreme Court. It must be noted that trials cannot be finished in a day as there is a long queue of trials with thousands trials lining every year in the Supreme Court of Indonesia. As such, the higher the court and the longer the processes are, the more expensive the cost will be. Therefore, legal pluralism and local wisdom is the most beneficial in terms of time consuming and cost coverage. It becomes a smart choice to resolve the existing conflicts among society members.

In addition, when assuming that the conflicts occurring in simpler societies may not be as complex as the cases in the bigger cities, it would be more efficient to resolve grievances in traditional societies within the scope of the society adhering to their customary laws. In effect, it takes less time to meet the arbitrators from the local leaders or other revered figures that they deem as trustworthy and can help solve the conflict. In addition, it would be less costly as they would not require to hire a lawyer or would not have to travel all the way to town. The time they take to queue with other trials and present in court would be worth more if they use it to carry out their day to day activities to fulfill their livelihood. As such, they do not leave their jobs and duties back in their village or rural area only to be present in court without no assurance of attaining the justice they deserve.

Economic sources become determinant factor for getting rights and just. So, formal justice has its own price meanwhile under-privileged citizens have economic limitation in affording the price for justice. They do not is the position of asking when and how to protect their rights and attain justice.

\section{CONCLUSION}

The inadequacy of the formal, state judiciary system to cater the needs and condition of the underprivileged society members is based on the focus on the procedural aspects that undermine the substantial aspects. In addition, scandals that have been associated with the state legal apparatuses as well as the preconceived notion of the society that the government and companies repress the voices and the rights of the weaker members of society renders society to distrust the existing formal legal apparatus. As such, in a very diverse society, the government may opt for legal pluralism to enhance the access of the members of society which had been out of the scope of legal access throughout the years. Legal pluralism merges the local wisdom of the remote societies that has been established since the beginning and well embodied throughout generations. It is considered to be less costly, less timely, less likely to ignite any other dispute. Besides that it can result in contentment and can be considered the most feasible option to ensure access not only for the underprivileged, but also for all members of society. Therefore, social justice mechanism has to be recognized and adopted within the Indonesian national judiciary system. 


\section{REFERENCES}

[1] Bedner, A. \&. (2010). An Analytical Framework for Empirical Research . Law, Social Justice \& Global Development Journal (LGD).

[2] Benda-Beckmann. (2002). Who's Afraid of Legal Pluralism? . The Journal of Legal Pluralism and Unofficial Law

[3] Chalid, Pheni (2016). Trust: Economic Capital and Social Transaction. Jakarta: Center for Social Economic Studies.

[4] Franco, S. M. (2010). Contemporary Discourses and Contestations around Pro-Poor Land Policies and Land Governance. Journal of Agrarian Change, Vol. 10 No. 1, pp. 1-32.

[5] Gebeye, B. A. (2017). Decoding legal pluralism in Africa. The Journal of Legal Pluralism and Unofficial Law , 228-249.

[6] Nugroho, J. (2015). Legal Pluralism as a Conflict Resolution Alternative of Law State and Local Wisdom in Water Resources Management Based on Social Justice (Case Study: in the Community of Water User Farmers the Regency of Lumajang East Java Province). Journal of Law, Policy, and Globalization., Vol 40.
[7] Nwocha, M. E. (2016). Customary Law, Social Development and Administration of Justice in Nigeria. Beijing Law Review, 430-442.

[8] Pal, Sarmistha. (2010). Social Norms, Culture, and Local Infrastructure: Evidence from a Decentralized Economy. RAND Corporation.

[9] Puddephat, A. (2009). Exploring the Role of Civil Society in the Formulation and Adoption of Access to Information Laws The Cases of Bulgaria, India, Mexico, South Africa, and the United Kingdom. Washington, DC: World Bank Institute.

[10] Röder, T. J. (2013). Informal Justice Systems: Challenges and Perspectives. Max Planck Institute for Comparative Public Law and International Law.

[11] Susan, N. (2015). Democracy, Land Conflict and Governance in Indonesia: A Case Study of Land Conflict in Lampung Province (20102012). The Graduate School of Global Studies, Doshisha University.

[12] UNDP, B. a. (2014). Legal Empowerment and Assistance.

[13] Wojkowska, E. (2006). How Informal Justice Systems can contribute. United Nations Development Programme Oslo. 